\title{
The Political Economy of Post-War Reconstruction in Sri Lanka: Development-Security Nexus vs. Tamil Right to Self-Determination
}

\author{
Jude Lal Fernando
}

\begin{abstract}
Post-war reconstruction in Sri Lanka, which is aided by many countries, is aimed at consolidating the unitary state structure as part of a geo-strategic security complex in the Indian Ocean Region. In this process, discourses of democratization and human rights have been reconfigured to contain or totally remove any threat to the unitary state emerging from the Tamils in the North and East whose claim to selfdetermination is seen as a major challenge to the geo-strategic complex in South Asia. In such a context, the bio-politics of the development-security nexus and neoliberal governmentality operates by strengthening the hegemony of the Sinhala state against the Tamils and weakening or destroying the essential foundations of Tamil nationhood. Without recognizing these local and global dynamics every peacebuilding attempt will fail.
\end{abstract}

Keywords unitary state, geo-politics, development, human rights, war, Indian Ocean Region

\section{Introduction}

With great erudition, Mark Duffield has shown how/why the way in which poverty, underdevelopment, and unevendevelopment is analyzed by apex intergovernmental institutions and major donor countries has changed radically in the aftermath of the Cold War. During the Cold War era, poverty was seen as a result of structural inequalities between the Global South and North, but in the post-Cold War period it is being analyzed as a security threat; poverty is a breeding ground for the formation of different forms of armed groups who could develop transnational networks through various mechanisms in the global economy. This is a threat emerging from within a state that can upset the existing global order (Duffield 2001). In this sense, human insecurity caused by poverty 
carries the potential to cause state and global insecurity. In other words, the objective of human security is to prevent civil conflicts that can have a ripple effect across state borders and internationalize the network of armed groups (Duffield 2005). Human security and development have been merged together in order to fulfill the conditions for state and global security (Word Bank 2011). Such conditions are dependent upon the way in which development and human security strategies are adopted.

Human security means to protect "the vital core of all human lives in ways that enhance human freedoms and human fulfillment" (Commission on Human Security 2003, 10). This definition goes beyond mere protection of lives from poverty and violence. It also aims "to empower them to act on their own behalf" (ibid., 2), signifying development that enables the masses to enhance their choices and freedoms (Shani 2014, 124). Here, development means absorption of societies as individuals into the global market. The strategy used is neo-liberal governmenatlity which reduces humanity to a bunch of rational autonomous individual consumers who have needs and wants rather than citizens of a postcolonial sovereign nation-state who have collective rights to distinct identity, land, territory, economic wellbeing, and welfare. Instead of an imperial peace achieved through regulatory governance during the colonial phase, it is a liberal peace that has been promoted which is a Western intervention that seeks to reconstruct the lives of populations of conflict-ridden non-Western states through bio-politics whereby satisfying the unmet needs of these masses through economic and social engineering (Duffield 2007, 129). ${ }^{1}$

The liberal peace model is utilized in the reconstruction processes of postconflict and post-war countries by imposing neo-liberal governmentality with the aim of containing conflict and violence that would destabilize the state and the existing global order. Democratization is the other feature of liberal peace, which means establishing mechanisms of liberal democracy whereby electoral, legal, and human rights mechanisms are set up. In this sense, human rights standards are mostly defined as an individual discourse. Often in the literature, one can see exceptional critiques of the neo-liberal governmentality imposed on postconflict and post-war societies (Richmond 2011; Williams and McGinty 2011). Similarly, as shown above, securitization of development has also been wellscrutinized (Duffield 2001; 2007). However, the Western approach is not simply based on an economic and racial binary of "insured" and "uninsured lives" (Duffield 2007, 129). Both neo-liberal governmentality and the developmentsecurity nexus operate as part of a geo-strategic security complex, which has not received sufficient attention from many scholars. In other words, bio-politics is an extension of geopolitics. Furthermore, within this complex, the ambivalent character of liberal peace that produces different outcomes at different times has not been properly identified in a nuanced way. In an asymmetrical power relationship between the parties in conflict, liberal peace can favor the dominant 
ethno-nationalist composition of a state as part of a geo-strategic complex revealing its illiberal politics. In a symmetrical relationship, liberal peace could bring about a different outcome in facilitating a negotiated settlement. I argue the importance of considering the geo-strategic dimension in critiquing neo-liberal governmentality and the development-security nexus by analyzing the case of Sri Lanka with a particular focus on various post-war development schemes and the human rights discourse in that country.

The case of Sri Lanka provides us with ample evidence of this geo-strategic security complex within which the post-war reconstruction processes are designed and implemented to reinforce one dominant nationalist discourse whilst dismantling another. The political economy of post-war reconstruction has been determined by a move to integrate the whole island, particularly the North and East, into a geo-strategic security complex in the Indian Ocean Region. I argue that the liberal peace transition during post-war reconstruction has to be analyzed as part of consolidating the military victory of the Sri Lankan state over the Liberation Tigers of Tamil Eelam (LTTE) in 2009 as opposed to the attempts made through the 2002 peace process for a negotiated settlement. The political economy of the post-war phase is aimed at totally dismantling the foundations of the Tamils as a nation. It is the military victory that reinstated the unitary state structure of the island, which has served as a strategic asset to Western powers since colonial times. The LTTE had built a Tamil state in the North and East of the island posing a challenge to the geo-strategic security complex in Asia, mainly led by the U.S. and U.K. governments.

Reduction of human rights standards to individual rights by the United Nations Human Rights Council (UNHRC) resolutions on Sri Lanka that do not recognize the collective rights of the Tamils serves a geo-strategic complex in South Asia. As the resolutions have upheld the existing state structure, the sovereignty of the Sinhala-dominated state has been reinforced. Similarly, neoliberal governmentality can weaken the collective ethno-nationalist consciousness in reducing communities to mere consumers. However, this consumerism is not abstract, but ideologically flavored with the victorious Sinhala nationalism. The development-security nexus is intrinsically a militarized development process, and neo-liberal governmentality has been Sinhalacised and perceived as an economic boom won through the military victory of Sinhala security forces. Within the same process, Tamil culture is being commoditized as part of Sri Lankan identity. Even though Western governments advocate rule of law and mechanisms of accountability, it is the majoritarian Sinhala Buddhist ideology that predominates every sphere of life, which is the internal social and political force that sustains the development-security complex. The bio-politics of neoliberal governmentality has reinforced the dominant form of ethno-nationalism. In such a geo-strategic complex, the development-security nexus goes against the collective imagination of human rights by the Tamils in the form of self- 
determination. Individualization of human rights could give a liberal appearance to an illiberal state and a development discourse. That is why I have juxtaposed the development-security nexus with the Tamil (collective) right to selfdetermination.

The key to my analysis is contextualization of Sri Lanka as part of a geostrategic complex in Asia. It is in that light we can understand the political economy of post-war reconstruction on the island, particularly in the North and East. Before venturing into the post-war phase, let me first briefly analyze the formation of the unitary political structure of the island as part of a geo-strategic complex by the British colonial rule. Secondly, I will point out how the political economy of the post-colonial nation-building phase was directed towards further strengthening the unitary political structure and converted it into a unitary state, as opposed to the Tamil demand for a devolution of power. Thirdly, it will be shown how the Sri Lankan state went into an economic and political crisis after the twenty year long war (1982-2002) against the Tamil liberation struggle which succeeded in forming a de facto state in the North and East. The crisis led to the 2002 peace process. The military and political gains of the LTTE understandably problematized the geo-strategic complex in Asia. As a result, the Sri Lankan state was militarily and politically empowered, mainly by the U.S. and U.K. governments, to dismantle the peace process (2002-2006), subsequently leading to the war (2007-2009) that totally destroyed the Tamil state with a cost of hundreds of thousands of lives. Finally, I will demonstrate in detail how the political economy of the post-war era is geared towards further consolidating the unitary state by totally dismantling the remaining foundations of the Tamils as a distinct nation. In that, I will show how during the last fifteen years there have been two approaches to development: post-conflict development based on transforming the unitary state through shared sovereignty (2002 peace process), and post-war development which absolutizes the unitary state with single sovereignty (after the 2009 military victory). In the later phase, the developmentsecurity nexus operates as a coordinated program of actions that dismantles the collective rights of the Tamils and their relationship to the North and East, which constitutes the core of their collective right. It is this exact right that poses a challenge to the geo-strategic security complex. Without analyzing this broad reality, the political economy of post-war reconstruction and the challenges it poses to peacebuilding cannot be understood.

\section{The Colonial Political Economy and the Unitary Political Structure}

In 1833, the British colonial rule, in its move to transform the island into a strategic location in the Indian Ocean Region, amalgamated distinct regions into a unitary political structure. Economically, India was the "Jewel in the Crown" for 
the British, which provided material for the Industrial Revolution. With the aim of controlling India, the island was treated as a military foothold which needed to be kept as a single unit under a single command to maximize its strategic utility. This geo-strategic complex in the Indian Ocean Region shaped the political economy of the island. The traditional landownership of the aristocrats and the monks was kept intact as a measure of maintaining internal political stability. On the contrary, India was exploited immensely to the extent of causing displacement of peasants from their lands and causing pauperization. In Sri Lanka, in the initial stage of plantations, the British acquired wasteland and the Sinhala peasants continued to own land even after the plantation sector was established. Therefore, the Tamil laborers from South India were brought in to work on the plantations in the Central Province which generated the wealth of the colony. As the local elite joined the sector in the second phase of the plantations, some sections of the Sinhala peasantry lost their land.

The plantation economy also generated a service economy involving transportation, food, timber, trading, etc., which brought about a new mercantile class who also later joined the plantations and formed the emerging political leadership of the island. The political economy of the colony was based on dependent capitalism (Ponnambalam 1980). This dependency was necessary in maintaining the much needed unitary political structure. In a move to include the landless Sinhala peasants into the state, the British established a welfare state by establishing Sinhala settlements in traditionally Tamil regions along the borders of the North and East. The ancient Buddhist archeological sites were regenerated in the North-central Province whilst the colonial officers translated the ancient Pali chronicle Mahavamsa into English, depicting the history of the island as one of conflict between Tamils and Sinhalese (Jeganathan 1995). Sinhalese were portrayed as superior Aryans and Tamils as inferior Dravidians who had invaded the island from South India (Angnell 2000). As the Indian freedom struggle gained momentum, the British geo-strategic complex needed to expedite separation of India from the island in consolidating the latter as a strategic foothold. This was accomplished by politically incorporating the Sinhalese, who are numerically a majority in Sri Lanka, into the unitary political structure. Constitutional reforms were introduced to facilitate representation of the local landed elite in the State Council and universal suffrage was granted to the colony in 1932. In this way, the character of the Sri Lankan state and its attendant political economy have been conditioned by a geo-strategic complex; its main features are the unitary state, dependent capitalism, and racial ideology. Dependent capitalism was necessary to maintain the subservience of the local ruling elite to the British establishment. Racial superiority was needed to garner internal Sinhala cohesion against the Tamils who were more culturally akin to India and more politically tuned into the Indian freedom struggle than the Sinhalese. The unitary political structure was essential to keep the island as one 
single unit under one single command. By the time of independence in 1948, the geo-strategic security complex and the construction of its economic, political, and ideological base had been completed.

\section{The Post-colonial Economy and the Unitary State Structure}

The post-colonial nation-building process has been a continuation and a consolidation of the colonial process. This phase accentuated the exclusion of the Tamils from the state and its economy. Immediately after independence in 1948, the citizenship rights of thousands of Tamils on the plantations were abrogated in a move to consolidate the Sinhala electoral constituencies in the region. A rapid settlement program was undertaken for the landless Sinhala peasants, virtually colonizing border regions of the Tamil areas in the North and East. The Tamils in the North and East who had a very limited amount of arable land were affected by these schemes. The Tamils could not expand their agriculture to suit the needs of the increasing population. In fact, the Sinhala landless peasants were brought from the South as far as the border regions despite the fact that there were large areas of unused land in the South. This shows that Sinhala settlements have a strategic edge against the Tamils. In a move to incorporate the intermediary Sinhala social classes, who were vernacular-educated and had been excluded during the colonial rule from state and public sector employment, Sinhala was made the only official language in 1956 excluding the Tamils. As dependent capitalism could not grow beyond its colonial confinements, the emerging generation of Sinhala-educated youth led by Janatha Vimukthi Peramuna (JVP, The Peoples' Liberation Front) revolted against the government in the early 1970s, and this led to the massacre of over 10,000 men and women by the state security forces and police. After the massacre, in a move to incorporate the disillusioned Sinhala youth into the state, a preferential quota system was introduced that would make it easier for the rural Sinhala youth to enter universities than the Tamils. This had a negative impact on the Tamil youth, particularly in the Jaffna Peninsula where education had become the key to employment in the absence of other viable socio-economic opportunities.

Globally, this was the era of modernization for post-independence economies. Both the capitalist and socialist blocs initiated moves such as aiding irrigation and building factories. The factories that were built during this period were mostly in the predominantly Sinhala South. The irrigation systems that were built were connected with the Sinhala settlements in the border regions in the North and East. The unitary political structure was colonial and geo-strategic, and had been discriminating against the Tamils. The processes of industrialization as well as modernization of agriculture, which was aided by donor countries of both sides of the Cold War, treated the unitary political structure as a natural entity, 
which resulted in the strengthening of the Sinhala Buddhist nationalist ideology.

The Tamil polity's initial demand in the 1950s was for incorporation into the state in the form of administrative federalism based on language. Given their continuous exclusion from the state and violent suppression (through the antiTamil pogroms in the 1950s, 1960s, and 1970s) of their non-violent resistance, the Tamil polity began calling for a resolution in the 1970s for an independent state based on the principles of self-determination, nationhood, and a homeland in the North and East. This call coincided with the Sri Lankan state's entry into the global market economy and establishment of direct links with the American bloc as opposed to the Soviet bloc. The North and East were not only totally excluded from the market economy and from the development schemes initiated in the new era, but also were badly affected as the Tamil farmers had to compete with the low prices of imported agro-products. This affected the Sinhala farmers too. Some of them entered into the rapidly expanding service sector in the urban areas in the form of transportation, trade, etc. Some Tamils who had engaged in small and medium level trade in predominantly Sinhala areas were perceived as competitors by the Sinhala intermediary social classes (Perera 2000, 166-196). This resulted in another series of large-scale anti-Tamil pogroms in 1979, 1981, and 1983 carried out by Sinhala nationalist groups directly and indirectly aided by the government politicians and state security forces. These pogroms destroyed the remainder of the economic base of the Tamils and forced many of them to flee the country in unprecedented numbers. The Tamil political parties who called for an independent state were excluded from Parliament as a result of a law that prohibited any demand for separation. In the 1970s, Tamil politics became radicalized to the extent of not only resisting the Sri Lankan state militantly by the new generation of Tamil youth, but also creating material conditions for a Tamil state in the North and East.

The entry into the market economy also marked the entry into a new securitization process aided by the U.S. and U.K. governments, which resulted in upgrading the security forces by training them in counter-insurgency warfare and equipping them with the latest weaponry. The biggest irrigation development scheme in the history of the island, which stretched from the Central Province to the Eastern Province bordering the Tamil region, was undertaken during this period with the aid of the U.K. government. This included hydroelectric power plants, Sinhala settlements in the border region, construction of new roads, etc. A closer look at these projects reveals that some of the newly built infrastructure was meant for political and military purposes. A major region called Manalaru bordering the North and East was developed as a Sinhala settlement cum military complex. The roads were constructed to facilitate the movements of troops. The new Sinhala settlements were meant to function as buffer zones, which were created with Israeli advice. The civilians were armed as the Tamil militant groups claimed some of these areas as part of the Tamil homeland. A special police force 
with military training was formed (the Special Task Force) with training provided by Israel and British security services (Miller 2014). Neo-liberal governmentality and securitization of development unfolded within a geo-strategic complex by militarizing the Sri Lankan state against the Tamil nationalist movement.

As neo-liberal economic reforms came into effect with the establishment of Free Trade Zones, and privatization of land and state and public services in the Sinhala South, there was a massive militarization of the North and East aided by the United States, the United Kingdom, and Israel. The political economy was determined by neo-liberalism and illiberal militarization, which strengthened the unitary state structure and its accompanying ideology. The neo-liberal political economy has been intrinsically interwoven with a geo-strategic complex that necessitated the unitary state. At that time, this geo-strategic complex served to contain India, which was leaning towards the Soviet bloc (and also the containment of Soviet influence in the Indian Ocean Region). India had a closed economy and a different military paradigm, which had supported the Bangladeshi War of Independence whilst the United States backed Pakistan. During this period, the only parallel to Sri Lanka that one can find is Chile, which was heavily neo-liberalized and militarized under Pinochet who came to power by ousting Allende in the 1970s. It has to be noted that it is in these two countries that the first experiments of neo-liberal reforms in the Global South were conducted and the experiments were carried out rapidly. At the same time, these countries also entered into a highly advanced military phase. In Sri Lanka, the first executive President (after the change of the constitution in 1978), who spearheaded these changes, called himself one in line with the ancient Sinhala Buddhist kings of the island. The foreign-funded irrigation projects were depicted as moves to reinstate the ancient glory of an agrarian nation, which was portrayed to be a continuation of a Sinhala Buddhist nation from ancient times. As the attacks on military, police, and civilians increased with the rise of Tamil militancy, the notion that the Tamils were invaders was reified by the Sinhala political rhetoric and media.

India, in a move to contain the Western sphere of influence in the Indian Ocean Region, welcomed thousands of Tamils fleeing the island, but also encouraged the Tamil militancy by providing training camps in Tamil Nadu. In Sri Lanka, the bio-politics of controlling the population (mainly Sinhala) through the market economy and strategic politics of militarizing the state went hand in hand. However, within ten years of introducing a market economy, the Sinhala South went into a massive social and political crisis with the weakening of the welfare state. The vernacular-educated Sinhala youth who were excluded from the market economy revolted by the end of the 1980s for the second time led by the JVP. As the political crisis deepened, the Sri Lankan state entered into a pact with the Indian government (which had been changing its pro-Moscow orientation towards the end of the Cold War) whereby Indian troops were called into the Tamil North and East as part of a "peacekeeping mission." This enabled 
the Sri Lankan troops to engage in repressing the southern revolt. As a result, the state security forces killed over sixty thousand young Sinhala men and women. Later on, due to the military conflict between the LTTE (which had emerged as a formidable force) and the Indian troops, the latter had to withdraw which facilitated the formation of a Tamil state by the LTTE in many parts of the North and East beginning in the early 1990s. With the suppression of the southern revolt, the bio-politics of neo-liberal governmentality was further imposed on the Sinhala population with further privatization schemes as part of a liberal peace agenda. The resistance of the Sinhala state and public sector employees as well as university students never became formidable as these social classes were glued to the unitary state and its ideology of opposing the Tamils. A majority of the Sinhala intermediary classes supported the war drive of the state wholeheartedly. The JVP served as the leaders of these social classes who were suppressed by the same military machine of the unitary state which was formed to protect the geostrategic complex of the Indian Ocean Region against the Tamils.

The LTTE's military, political, and social gains gave them a popular appeal and the Tamils gained confidence in their efforts and belief that an independent state could be made a reality. The LTTE's ability to function as a conventional armed force whilst running a civil administration in seventy percent of the North and East posed the biggest challenge ever to the geo-strategic complex in the Indian Ocean Region since British colonial rule. Its political economy was mostly based on the financial support of the Tamil diaspora who ran businesses ranging from shipping lines to restaurants and retail shops in major cities mainly in the Global North. It also had introduced a taxation scheme in its territory and engaged in farming and running restaurants and fuel stations. Being able to run businesses worldwide is a result of the free market economy introduced by the capitalist mode of globalization. However, amongst the Tamils, these spaces were utilized for a national liberation struggle, which problematizes the geo-strategic military complex of capitalist globalization. Bio-politics of capitalist globalization could not control the Tamils as a population as long as they were resisting the Sri Lankan unitary state, which is a part of a geo-strategic complex of the major driving states of globalization. On the contrary, the Sri Lankan state's free market economic policies were accompanied by heavy militarization of the state that has become part of the geo-strategic complex in the Indian Ocean Region. For example, a free trade zone was established in between the largest air force and naval bases of the island in Western Province, which is predominantly a Sinhala region. As mentioned above, the irrigation schemes funded by foreign aid were meant to function as a military buffer zone in the North-central Province. Development infrastructure with foreign aid served both investors and security forces. The LTTE's attacks on the Central Bank in the capital and the biggest air force base cum international airport next to the free trade zone in the early 2000s put the Sri Lankan state and its international investors in a bind. Could the 
economy be sustained whilst waging a war? Could the kind of peace necessary for the markets be achieved without political negotiations with the LTTE regarding the unitary state structure?

After the Cold War, the U.S. and U.K. governments continued to further the development-security nexus through militarization across the world. Meanwhile, the European Union (EU), led by France and Germany, followed a different line, promoting demilitarization of conflicts through political negotiation to enable the market economy to thrive uninterruptedly. The latter promoted neo-liberal governmentality with an emphasis on democratization and human rights, which had the potential to contain strategic politics associated with militarization of the globe. This potential can be activated only when there is a formidable resistance emerging from the victims of strategic politics, like the Tamils. The 2002 peace process between the LTTE and the Sri Lankan state is a clear example of activating the constructive potential in the liberal peace model as opposed to continuance of imperial peace achieved through military pacification. Sri Lanka provided a unique opportunity to the EU to implement its investor-friendly and anti-war agenda. The EU's approach, even though neo-liberal, looked promising as long as it opposed war. Besides, this agenda also had outlined human rights standards for aid-recipient countries, which could function as a barrier against state violence as well as exploitation of the workforce and nature. It could also encourage highlighting the democratic demands of the militant organizations and bringing them to the political negotiating table. This unique opportunity was brought about by the balance of power reached between the LTTE and the Sri Lankan state by the early 2000s. It was a huge opportunity to demilitarize the conflict through political negotiations with the LTTE who had already built a state in the North and East which in effect had transformed the unitary state.

As the two major actors of the conflict had come to stop hostilities without any foreign intervention, this moment signaled a bottom-up approach to conflict resolution and peacebuilding rather than a top-down imposition of resolutions that serves the geo-strategic complex. The ambiguous meanings of liberal peace need to be understood by taking into account different moments in the politics of conflict and peace. The liberal peace initiatives of the post-conflict phase marked by the 2002 peace process are radically different from that of post-war phase marked by the military victory of the Sri Lankan state over the LTTE in 2009. The political economy of reconstruction and democratization in these two phases are equally radically different from one another. Why did the 2002 peace process fail?

\section{Development under Shared Sovereignty: The 2002 Peace Process}

In the aftermath of the Cold War whilst the EU and China had consolidated themselves as global powers, the United States and the United Kingdom 
continued to flex their muscles as military powers, particularly in the post-9/11 era. The contrasting positions of Germany and France and the United States and the United Kingdom concerning the invasion of Iraq clearly demonstrated two different approaches to resolving conflicts. The major EU countries advanced a political economy that would encourage parties in conflict to adopt political negotiations, meaning conflict resolution through development that would enhance markets for trade. The Sri Lankan state needed foreign aid to revive its economy. The LTTE needed foreign aid to reconstruct the North and East which had been devastated by decades of war. It also needed international recognition to pursue its goal of Tamil Eelam while converting its military gains into a peaceful political settlement. The Sri Lankan state could not have revived the economy without stopping the war and engaging in political dialogue with the LTTE. These mutual interests of both parties fitted very well with the EU approach. On the contrary the U.S. and U.K. governments upheld an agenda that would securitize (militarize) development, and would fit with their geo-strategic military complex. Even though the donor countries promised billions of U.S. dollars in development aid for peacebuilding in Sri Lanka, the 2002 peace process was immensely strained by the securitizing of development aid.

The U.S. government adopted a conservative approach to liberal peace; disarmament, demilitarization, and demobilization of one party, the LTTE, whilst enhancing the military capabilities of the Sri Lankan state. The geostrategic complex that was created through the unitary political structure of the island by British colonial rule became extremely pivotal as the U.S. invasion of Afghanistan and Iraq unfolded where South Asia and the Indian Ocean Region functioned as a buffer zone to the Middle East. Furthermore, maintaining the unitary state structure became very strategic in containing the growing Chinese sphere of influence in the region through its "String of Pearls." As a matter of fact, China sent a trade mission to meet with the LTTE leadership during the 2002 peace process. India aligned closely with the U.S. strategy in containing the Chinese sphere of influence. The joint subcommittees that were formed between the Sri Lankan state and the LTTE to facilitate rehabilitation, reconstruction, and demilitarization of the North and East created space for shared sovereignty between the Tamils and the Sinhalese. These subcommittees associated with the principle of shared sovereignty (like in the Irish peace process) carried an immense potential to reduce the geo-strategic military usability of the island. Within one year of the start of the peace process, the U.S. government securitized negotiations between the Sri Lankan state and the LTTE by fixing one of the two preparatory meetings for the biggest Tokyo donor meeting in Washington so that the LTTE was excluded, and this resulted in the breakdown of the peace process. The U.S. government had already sent a team of naval officers from its Pacific Command to the strategic Trincomalee Harbor in the Eastern Province soon after signing the 2002 Memorandum of Understanding (MoU) between the 
Sri Lankan state and the LTTE. This team provided a master plan to execute the future war (Moorcroft 2013). In 2007, the U. S. government entered into a formal military agreement with the Sri Lankan state in the form of the Acquisition and Cross Servicing Agreement (ACSA).

The training, which will encompass joint exercises with United States Armed Forces, will focus on counter terrorism and related activity... Neither Colombo nor Washington is willing to confirm the release of two maritime surveillance aircraft and one patrol ship to intensify surveillance over the eastern seas of Sri Lanka (Outlook 2007).

Around 1,000 Okinawa-based U.S. marines went to Sri Lanka to train the security forces in 2007. The end result was the implementation of the final solution that massacred over 70,000 people (United Nations 2012) whilst destroying the entire Tamil state structure with its civil administration in the North and East. With the military victory, the unitary state structure was reinstated whilst joint annual naval training sessions between the U.S. and Sri Lankan navies have resumed in Trincomalee Harbor after thirty years.

The political economy of the post-war reconstruction processes has to be evaluated with respect to the backdrop of the military victory; a victory that was meant to fully incorporate the entire North and East into the unitary state and thereby into the geo-strategic security complex in the Indian Ocean Region. As the wars in the Middle East continue and as the United States pivots to Asia in order to contain China, the Sri Lankan unitary state structure is central to the U.S./ U.K. sphere of influence in the region. Therefore, the Sinhala dominated postwar reconstruction process has to be understood not simply as a reflection of the bio-politics of the Western powers, but mainly as necessitated by the absolute importance of the unitary state structure associated with this geo-strategic complex. Bio-politics operate in strengthening the Sinhala nationalist mindset, which is necessary as an ideological base for the unitary state. The way in which post-war reconstruction takes place is a logical outcome of the way in which the final solution to the decades long national conflict was implemented.

The discourses of development and human security have been reconfigured to serve this consolidation. Therefore, reconstruction does not necessarily mean development and empowerment of the post-war victims, but reinforcement of a development-security (military) nexus that solidifies the unitary state and its ideology. I will point out how the international political economy operates in serving the consolidation of the unitary state structure and it geo-strategic complex through various means. In fact, the international actors including China, India, and the United States, compete for the same unitary state in the strategic island of the Indian Ocean-which is in close proximity to major maritime routes-for different conflicting reasons as part of a strategy to enhance one's own 
sphere of influence.

\section{Development-Security Nexus under Single Sovereignty: After the Military Victory in 2009}

Often in post-conflict countries, reconstruction processes have been undertaken by civilian governments distancing themselves from the military that was involved in the armed conflicts, like in East Timor, Nepal, Northern Ireland, Guatemala, and El Salvador. In Guatemala, as the military was highly responsible for mass crimes, one of the clauses of the peace process was to distance the military from reconstruction processes. In Northern Ireland, after the Good Friday Agreement in 1995, British military camps were removed. In the 2002 peace process in Sri Lanka, the MoU stipulated that the military should hand over vast swaths of civilian land to their original Tamil inhabitants. It was an attempt to separate the military, which is the tool of the state, from the Tamil civilians. Such a phase could have been called a post-conflict situation. On the contrary, the post-war reconstruction process is a continuation of the implementation of the objectives of the war; the consolidation of the geo-strategic complex and its essential component, the unitary state. It has multiple approaches targeting different sociopolitical dimensions of the Tamil nationalist movement, which was considered a threat to the unitary state and its geo-strategic complex. The discourse of reconciliation is the most dominant narrative in post-war era promoted by the Sri Lankan government, Western donor countries, and Sinhala civil society. As a matter of fact, the war was waged not with this objective. The major international actors heavily supported it with the sole purpose of regaining the unitary state, but not to share sovereignty of the island with the Tamils as part of peacebuilding and reconciliation. Therefore, there is no moral, political, or legal pressure or obligation on the Sri Lankan state to change its course of action.

There are two main sets of features of the post-war development-security nexus. The first set is structural changes through military intervention in the socioeconomic life of the North and East through large scale militarization, acquisition of land and major centers of commercial and economic value, control of the civil administration, control of resettlement and rehabilitation by the military, building of militarily strategic infrastructure, military involvement in various types of economic activity, establishment of Sinhala settlements, and Sinhala Buddhicisation. The second set of features is the political reconfiguration of the conflict by which the victims of mass atrocities have been asked to seek justice under the unitary state; criminal justice sans political justice by depicting mass atrocities as individual human rights violations or aberrations rather than a systematic and coordinated structural attack on a distinct group of people in the country. The main political cause of the conflict-the unitary state- 
is unquestioned. Reconstruction is defined here not only as a developmental process, but also as a sociopolitical process whereby the way in which human rights discourse is narrowly defined under the existing state structure by reducing it to criminal justice without political content. According to the Sri Lankan government, even such a criminal justice process has to be led not by an independent international body, but by local judges who come under the Sri Lankan state. In an interview with the $B B C$, the Sri Lankan President stated, "this investigation should be internal and indigenous, without violating the laws of the country, and I believe in the judicial system and other relevant authorities in this regard. The international community need not worry about matters of state interest" (Ameen 2016). Approving the Sri Lankan government's approach to development and human rights, a high ranking U.S. state department official who visited the country stated, "your success in rebuilding your country and reconciling your people will be an example to the rest of the world, so fraught with conflict at this time. The United Sates is proud to be a partner in this effort and proud to be an ally of Sri Lanka" (DailyFT 2015). These statements reflect how reconstruction and human rights discourses have served the consolidation of the unitary state after the military victory. The same state structure has been heavily backed for different reasons by the global actors ranging from China and India to the United States as well as by the intergovernmental donor agencies such the Asian Development Bank, UN agencies, the World Bank, the International Monetary Fund (IMF), the United States Agency for International Development (USAID), etc.

\section{Large Scale Militarization}

In the northern peninsula of Jaffna, the troop density is one to five, which means one soldier for one Tamil family. This ratio exceeds the military-civilian ratio in Chechnya, Kashmir, and Baghdad (just after the U.S. invasion) (A Correspondent 2012, 35-36). By 2012, fourteen out of nineteen divisions of the Sri Lankan Army had been stationed in the North (Nirupama Subramanian 2012). Even after the post-war regime change in 2015 this number remains the same. The new regime of 2015 has categorically stated that it will not scale down the military presence in the region. One report reveals as follows:

These fourteen divisions are spread out under the control of three Security Forces Head Quarters-in Jaffna, Kilinochchi and the Vanni (encompassing the administrative districts of Vavuniya and Mannar). The Kilinochchi and Vanni Security Forces Head Quarters were established post-war. All three divisions under the Kilinochchi SFHQ were formed during the war between 2007 and 2009. The Wanni SFHQ contains of five divisions, two of which were created in 2010-the one in Thalladi, Mannar and one in Manalaru (Weli Oya) in Mullaithivu. Manalaru is a controversial area where Tamils allege the Sri Lankan Governments since the 1980s have been interested in colonizing with Sinhalese so as to create a disconnect 
between the Northern and Eastern Provinces (which Tamil politics have claimed to form the contiguous areas of their historical habitation and hence the territorial unit for autonomy). The Jaffna SFHQ consists of three divisions. All security forces headquarters also have affiliated units (Maatram Foundation 2015, 3).

Declaring the Manalaru Camp, which is located in the border areas of the North and East, as one of the military headquarters is an attempt to dismantle the contiguity of the traditional Tamil region. The same report gives detailed accounts of 117 small, medium, and large scale military camps in the Jaffna District alone, which also houses the largest high security zone in Palali. According to the Jaffna District Secretariat, 8,500 landowning families have been uprooted due to militarization of the district (Tamilnet 2017). Furthermore, military cantonments are being built next to the military bases to permanently house the families of soldiers. There are at least 150,000 security force personnel in the North and East. The 40 percent increase of the defense budget during the final years of the war and the subsequent 15 percent increase in the immediate aftermath of the war have not been reduced even though seven years have passed since the official end of the war (Höglund and Orjuela 2011,26). The military occupies most strategic locations in the region, particularly along the coast as they have fenced off some of the key fishing villages and ports barring access to their original inhabitants.

This military strategy clearly overlaps with the U.S. government's increasing military relationship with the Sri Lankan state. In July 2016, then U.S. Assistant Secretary of State for South Asia Nisha Biswal, during her visit to Sri Lanka, reiterated the need to enhance maritime military-to-military cooperation with the island (Tamilnet 2016). Sri Lanka hosted a major maritime security conference in 2016 attended by Admiral Harry B. Harris, Jr., Commander of U.S. Pacific Command, who stated that "oceans that once were physical and psychological barriers that kept us apart are now maritime superhighways that bring us together" (U.S. Embassy in Sri Lanka 2016). He also visited the strategic harbor of Trincomalee where U.S. marines are involved in training the Sri Lankan navy (ibid.). In this way, militarizing the Tamils has become an essential component of post-war reconstruction process. Even though there is an attempt made by states as well as local and international civil society groups to separate the LTTE from the Tamil people, the reason behind the militarization of the Tamil people even after the war is the continuing prevalence of the collective consciousness and political aspiration of the Tamil people that gave rise to the LTTE. Post-war reconstruction is designed as a process of militarization whereby the geo-strategic complex surrounding the unitary state is consolidated.

\section{Acquisition of Land and Major Centers of Commercial and Economic Value}

The process of militarization is intrinsically interwoven with large scale acquisition of vast tracts of civilian land. Out of 18,000 square kilometers of total 
landmass in the North and East, the security forces have acquired 7,000 square $\mathrm{km}$ (A Correspondent 2012, 37). The Sri Lankan state justifies its acquisition of land by the military on the basis of Land Development Ordinance of 1935, which was introduced by the colonial government in collaboration with the Sinhala ruling elite. Under this law, land can be acquired by the state to initiate different development projects and settlements. This has served throughout history in favor of the Sinhalese as opposed to the Tamils as shown earlier in the historical roots of the conflict. Land laws that were promulgated to strengthen the unitary state structure during colonial rule have regained prominence in post-war reconstruction, which in essence is militarization.

In a debate held on the 10th of October 2014 at the Northern Provincial Council members provided statistics from three districts which suggested that more than 67,000 acres of land had been taken over for use by the military in the districts of Jaffna, Mullaithivu and Mannar. In Jaffna according to NPC statistics 10,919 acres, in Mullaithivu 34,362 acres and Mannar 22,247 acres have been taken over for military use. It was stressed that this was only a conservative estimate and that the figure could be more than reported (Maatram Foundation 2015, 6).

In these lands, in addition to maintaining military structures, the security forces engage in farming, food processing, providing houses for the local tourists, etc. It has to be noted that some of these lands were full of residential areas. Moreover, the most fertile swath of land covering 4,589 acres in Valikamam, in the northern part of the Jaffna Peninsula, has been occupied by the military for decades (Tamilnet 2017). The navy also engages in fishing. Mullikulam and Mayliddi are rich fishing villages whose original inhabitants are barred from entry. The security forces engage in tourism and have built tourist resorts in Kankasanthurai and in Chundikum. It also runs a range of restaurants, minisupermarkets, and barbershops across the region. Some of these are located adjoining the A9 main road that connects the North and South. This is the road that is being frequently used by thousands of local and foreign tourists daily. In addition to these, the military runs large-scale farms and war museums. Permanent structures have been built as part of this business-military complex. The above report points out how the government has publicly acknowledged that in the Kilinochchi District alone there are twelve military-run farms where pulses, maize, and groundnut are grown using modern technology and around 2,500 people are employed in these farms. Some of them are political prisoners, and a majority of the farm workers are women (Maatram Foundation 2015, 15). Kilinochchi District is an agrarian region, which has very good soil and water resources. It is also a region that was severally affected by war displacing and destroying all most all the villages. As the military has engaged in farming and many other businesses, the Tamils who have been resettled in these areas have little access to means of income. Even the small number of Tamil farmers 
who have started farming cannot compete with the low prices of products of the military farms. The military can provide these products at a low cost due to cheap labor and large-scale farming. It is military cooperatism that has been formed as part of post-war reconstruction, which makes the military an integral component of the North and East. The impact of this integration is destruction of the essential economic foundation of the Tamil nation.

In merging development with state and human security, USAID has aided a range of community development projects in the name of sustainable development while promoting small and medium scale businesses in the region. Its website introduces Sri Lanka as "an island nation located along major maritime trade routes in the Indian Ocean, [which] is currently experiencing steady economic growth following twenty-six years of conflict and a disastrous tsunami in 2004" (USAID 2016). Its mission statement says that the agency works to "enable...democratic societies to realize their potential" (ibid.). This potential is associated with the island's strategic value. Economic growth and democratic institutions-as a form of bio-politics that aims to contain the security threat caused by poverty and marginalization-are necessary to secure this geo-strategic value. The liberal peace model characterized by development and democratization is utilized as part of geo-politics. The implementation of a program for democratization with a US\$ 13.7 million grant provided by USAID has been entrusted to Development Alternative Inc., a private firm which is known to have close links with the U.S. Central Intelligence Agency (Kurukulasuriya 2017). These alliances will have an impact on the way in which the human rights discourse, particularly concerning the Tamils, is framed, and this will be discussed later. In following the same paradigm to a different degree, China has aided in building houses for the military in the North and East in an attempt to counter the U.S. sphere of influence on the island. It has been reported that the Chinese government granted more than US\$100 million for said purpose in 2012 (Sirimanna 2012). In this way, the political economy is determined by global actors who are competing for the same island that cannot be utilized as a strategic asset without maintaining it as a unitary state. In what way does this affect resettlement and rehabilitation processes?

\section{Military Control of Rehabilitation and Resettlement}

Rehabilitation and reconstruction are key factors of post-conflict and postwar situations. At least half a million people lived under the Tamil state during the 2002 peace process, which covered around 15,000 square kilometers. With the multiple-pronged military operations launched by the Sri Lankan security forces (2007-2009) at least around 350,000 civilians were forced to flee to the Sri Lankan state-controlled areas. In the last phase of the war, based on government's own statistics, the bishop of Mannar has stated that there are at least 147,000 unaccounted for civilians (Oakland Institute 2015, 4). Those who came to these 
areas were detained in poorly built refugee camps for nearly three years. These camps, which were coded as "welfare centers" and aided by UN agencies, were in fact concentration camps where arrests, disappearances, torture, and rape had become a daily occurrence. The Sri Lankan military strictly vetted the refugees. Those who were suspected of having even the slightest link with the LTTE were arrested and kept incommunicado. According to official figures, around 11,825 people were considered to be "terrorist suspects" in the initial stage in 2009. By the end of 2016, this figure dropped to a couple hundred. The Sri Lankan state's rehabilitation program has been fully managed by its security forces. It did not follow any international standards, nor was an independent monitoring body established. Some detainees were recruited as informants; others were formed into a civil defense force. Many who were released had to go through constant surveillance by the security forces. The female ex-combatants were sexually abused by the security forces. A detailed report on torture and sexual violence produced by a member of the UN panel of experts on Sri Lanka describes many such cases both while the refugee camps were being operated and after their closure. The report notes as follows:

The Government of Sri Lanka's extensive intelligence system, shared by the security forces and immigration officials, benefitted from the extensive documentation of Tamils by security forces at the end of the war. They recorded details of all IDPS's such as names, locations, addresses, details of family members, including their locations and also took their photographs (Sooka 2014, 7).

Furthermore, it has been revealed that some of the released ex-combatants have fallen critically ill. They were never recognized as political prisoners. At the time of writing, evidence has emerged that the military had inoculated prisoners with poisonous substances. No intergovernmental bodies like the UN or the EU, nor individual donor countries and allies of the Sri Lankan state, sought to reverse this process. In this sense, rehabilitation has been intrinsically interwoven with militarization and furtherance of counter-insurgency warfare, which is aimed at curbing any potential threat emerging from Tamil militancy to the unitary state.

Three years after the official end of the war, resettlement of over 300,000 displaced Tamils was conducted within the above-mentioned strategic and military plan. Many have been prevented from returning to their places of origin. They have been resettled in formerly uninhabited land near forests infested with snakes and mosquitos. In both the official definition, and in practice, there has been serious ambiguity in the words "resettlement" and "return." These words have been interchangeably used, but not all those who were resettled returned to their lands of origin. Even those who returned to their homes had to live in a totally militarized situation and suffered from a lack of basic facilities, such as water, housing, schools, medical facilities, livelihood, etc. After many interviews 
with the victims, one report states that "the people of Sampoor demand their original homeland, which is 'full of resources for livelihood such as the paddy fields, agricultural farm and fishing areas.' The alternate lands offered by the government allegedly not only lack the above but also basic facilities, such as drinking water" (Oakland Institute 2015, 10).

Virtually every village in the North and East has a military camp. The war widows suffer through sexual harassment on a daily basis. After three years, the Sri Lankan state claimed that it had completed the process of resettlement. By January 2, 2012, the official statistics said 236,429 had been resettled. On September 25, 2012, the so called refugee camps were closed with the resettlement of the last batch of refugees in the Mullaitivu District in the Northern Province. The Presidential Task Force for Resettlement, established after the military victory and headed by then President Mahinda Rajapaksa's brother, was a fully Sinhala Colombo-based committee. In fact, it was the security forces that were coordinating and monitoring resettlement. Its commander was the Competent Authority for Internally Displaced Persons (IDPs) set up in September 2012 who declared that "there will be no more IDPs in the country" (Daily Mirror 2012). UN agencies and bi-lateral donor agencies, including USAID and many others, hailed the return of the refugees. However, none of them questioned the highly militarized resettlement process, which has been an essential part of the development-security nexus.

According to the UN Human Settlements Programme, UN-HABITAT, 143,268 houses have to be repaired or rebuilt in the region (IRIN 2013). How does the international political economy of the reconstruction of houses operate? The Indian central government, which aided the execution of war, had to balance between its alliance with the U.S.-led geo-strategic complex against China and the domestic opposition in the state of Tamil Nadu against the war on Tamils. Within Tamil Nadu, there is a large wave of sympathy towards the Tamil victims of the war. As a balancing act, the Indian government promised construction of 49,000 houses at a cost of US\$ 260 million. A Mumbai-based Indian company was contracted to build these houses. According to one news report, this "company will manage the project to build 12,500 houses in the Kilinochchi District, a similar number in the Mullaitivu District, 10,000 houses in Vavuniya and 15,000 in Jaffna and Mannar, under the supervision of the Government of India" (Sirimanna 2010). In addition to the Chinese government's aid for building houses for the families of security forces as stated earlier, Chinese companies have engaged in large-scale investments for building highways, an industrial farm, a harbor, and a coal power plant (ibid.). Both Asian giants seem to compete with one another to help consolidate the unitary state in the post-war era.

Whilst the United States entered into a military pact with the Sri Lankan state during the war, both China and India have gained contracts for mega development projects on the island in the post-war era. There are four Chinese 
companies that are engaged in building special economic zones, a coal power plant, and expressways in the South and railroads in the North. Around $332 \mathrm{~km}$ of roads with a highway will be developed and modernized with Chinese funding of US\$ 355 million. South Korea, which is one of the United States' closet allies in Asia, has signed an agreement with the Sri Lankan state worth of US\$ 63.2 billion to build nine smart cities around the Colombo area (Korea Herald 2016). It will be shown below how Japan, the other major U.S. ally in Asia, is involved in a project that further strengthens the Sinhala Buddhist ideology by promoting tourism to the North and East. These projects normalize the military victory achieved through mass atrocities as the subsequent development-security nexus. These are seen as part of a post-war economic boom that can eventually be credited to the Sri Lankan security forces who claim that it is engaged in a $5 \mathrm{R}$ (Rehabilitation, Reintegration, Reconstruction, Resettlement, and Reconciliation) process for the Sri Lankan state in the North and East.

\section{Establishment of Sinhala Settlements and Sinhala Buddhicisation}

In the resettlement programs, it has been noted how reconstruction of Sinhala villages in the North and East have been given priority. One such instance is the Sinhala village near Madhu Road in Mannar District. There are many such villages in the Eastern Province. Some of these were Sinhala settlements were were initiated by the Sri Lankan state prior to outbreak of the armed conflict. In addition to these, the post-war process of acquiring land is not only meant for militarization but also for new Sinhala settlements. This serves both state security as well as demographic changes in the region. As the state is Sinhalese, these settlements become part of the state apparatus and the military. Sinhala settlements also weaken the Tamil constituency and the contiguity of the Tamil region in the North and East. Sinhala names have been introduced to many key regions.

This process is accompanied by Sinhala Buddhicisation of the region. In a 25,000 word long article published by Uppsala University in Sweden, I have shown how there are different types of locations where this process has unfolded (Fernando 2013). All most every military camp has a small or large Buddhist shrine. Most of these are built displaying the Buddha statues in public areas, which are totally, or predominantly, non-Buddhist. Buddhist stupas and monasteries have been built in key commercial places and strategic locations on the coast. There are also Buddhist temples that have been built either on Hindu sites or close to these sites. Ancient Tamil Buddhist sites have been renamed as Sinhala Buddhist sites.

Japan has become one of the leading countries that have promoted tourism to the island on the basis of an "ancient Sinhala Buddhist civilization" in the Tamil region. In a recent report compiled by the Japan Consortium for International Cooperation in Cultural Heritage and Japan Foundation Program for Cultural 
Cooperation, ancient Tamil cultural heritage has been renamed as Sinhala Buddhist cultural heritage in the North and East. In fact, this is the official as well as the Sinhala ultra-nationalist version of history of the island, which strengthens the ideological foundations of the unitary state. The report is entitled "Survey of Protection and Utilization of Cultural Property in Northern and Northeastern Provinces of Sri Lanka." It also claims that there exists "a cooperative relationship between the military and public works in Sri Lanka" (Japan Consortium of International Cooperation in Cultural Heritage 2015). During the 2002 peace process, Japan played a crucial role in utilizing the liberal peace model aimed at a negotiated settlement. It hosted a number of meetings between the Sri Lankan state and the LTTE whilst appointing a special envoy to the peace process. With a change in the balance of power after the military victory-which has helped the United States' pivot to Asia aimed at encircling China-Japan has changed its position in support of the unitary state and its nationalist ideology in Sri Lanka.

\section{Unitary State, Development-Security Nexus, and Human Rights}

Post-war reconstruction does not mean only the creation of a developmentsecurity nexus; it also means political reconstruction of the decades long national question, armed conflict, and military victory. In the immediate aftermath of the war, there was an outcry arising from many international human rights organizations against mass atrocities committed by the Sri Lankan state against the Tamil people. The Tamils called it genocide and the demand for independence was accentuated among them. Within six months of the final massacres in 2009, the Permanent People's Tribunal in Rome convened a People's Tribunal on Sri Lanka in Dublin, which was supported by many international human rights organizations. The Dublin Tribunal found the Sri Lankan state and its security forces guilty of war crimes and crimes against humanity and the U.S. and U.K. governments responsible for the break down of the 2002 peace process, which gradually paved the way for the final massacres (Permanent People's Tribunal 2010, 2013). The second phase of this Tribunal was held in the city of Bremen in Germany in 2013 and found that the Sri Lankan state is guilty of genocide and the U.S. and U.K. governments are complicit in aiding the Sri Lankan state.

With mounting international pressure, the Sri Lankan state appointed its own commission called the Lessons Learnt and Reconciliation Commission (LLRC). International human rights organizations such as Amnesty International, Human Rights Watch, and International Crisis Group boycotted this commission stating that it lacks credibility and is procedurally flawed. The LLRC report concluded that the state waged a legitimate war and its security forces did not commit any crimes, but it is the LTTE that committed crimes. It recommended establishment of the rule of law and a process of reconciliation under the unitary state. Amidst growing international pressure by human rights groups and the Tamils, the UN Secretary-General appointed a panel of experts to examine issues 
of accountability in Sri Lanka. Their report concluded that there is credible evidence of war crimes and crimes against humanity, and recommended that an international independent commission be appointed. It declared that at least 40,000 people were killed in the final phase of the war (United Nations 2011). Later on, another UN internal review stated that the number of those who were massacred could be as high as 70,000 (United Nations 2012).

It was at this juncture that the U.S. government intervened diplomatically in sponsoring a resolution on Sri Lanka at the UNHRC session in Geneva in 2013 (United Nations General Assembly 2013). The U.S.-sponsored resolution abandoned the UN's own report produced by a panel of experts as well as the internal review. Instead it grounded itself on the LLRC report and recommended that the Sri Lankan state investigate the last phase of the war. Many Tamil diaspora groups as well as the Tamil political leaders in the North and East were told in their meetings with U.S., U.K., and EU government officials that justice has to be sought through the UNHRC resolution. Those international human rights organizations that initially criticized the LLRC rallied around the UNHRC resolution. The first series of resolutions were passed in 2012, 2013, and 2014 during the Mahinda Rajapaksa regime, and the final one was passed in $2015 \mathrm{after}$ a regime change. These resolutions reiterated the content of the preamble of the Sri Lankan Constitution concerning territorial integrity and sovereignty which constitute the core of the unitary state. None of the resolutions use the word Tamil when referring to the victims. The word can be seen only in reference to the LTTE which is a seen as one of the perpetrators. It should also be noted that the first two UNHRC resolutions were opposed by China and other countries backed by China and they accused the United States of infringing on the sovereignty of Sri Lanka. As a matter of fact, Chinese influence grew faster on the island in the aftermath of the war, particularly through many investments and infrastructure construction projects as noted above. The apparent criticism of the Sri Lankan state through the UNHRC resolution by the Western governments was not necessarily due to its human rights violations, but mainly due China's growing influence on the island. One of the major accusations against the Mahinda Rajapaksa regime, which led the war, during the election campaign in 2015 was not about committing mass atrocities, but about nepotism and corruption associated with Chinese investments. This was also the tone of the Western states that tactically distanced themselves from the Rajapaksa regime even though the military agreement and the joint training sessions with the U.S. security forces continued. Some scholars argue that the Chinese influence has become the major obstacle for issues in conflict prevention.

Changes in the international power balance over the last decade have decreased the room of maneuver for actors such as the United States and European Union while giving Asian powers such as China-with a different approach to conflict 
prevention—more influence over domestic policies (Höglund and Orjuela 2011, 11).

In fact, China's opposition to the UNHRC resolution further strengthened the U.S. hold on Sri Lanka by concealing the U.S. government's consistent support given to the unitary state. The biggest obstacle to conflict prevention is protection of the unitary state. In terms of Sri Lanka, both in the international and local civil society, a false polarization between the U.S. and China has been created. Eventually, with the regime change in 2015, the UNHRC resolution was cosponsored both by the U.S. government and the Sri Lankan state and backed by China as well.

Through the UNHRC resolution, political justice (self-determination) has been traded for criminal justice. Tamil victims have been told to seek criminal justice under the unitary state structure. In fact, the new regime has not officially accepted that crimes were committed. John Kerry, then U.S. Secretary of State, in a press release issued on the UNHRC resolution in 2015 stated that transitional justice should be sought "while safeguarding the reputation of those, including within the military, who conducted themselves with honor and professionalism" (Kerry 2015). If there is an acceptance of crimes at all, they are classified as aberrations or deviations which are isolated individual cases, but not as systemic and coordinated crimes committed against the Tamil people by the Sri Lankan state and its allies in protecting the unitary state structure and its geo-strategic complex in Asia. Under the implementation of UNHRC resolution, a countrywide consultation for establishment of mechanisms for rule of law has started and are aided by donor countries. In this process, it is the human rights of all that have been reiterated, in general, meaning Sinhalese, Tamils, and Muslims. The distinct collective historical oppression and massacres experienced by Tamils under the unitary state structure and its accompanying discriminatory ideology and practices have not been dealt with in particular. Furthermore, the government has categorically rejected any participation of international judges in investigating human rights abuses.

In the post-war era, the political economy of EU aid to Sri Lankan state is associated with individualization of human rights whilst maintaining the development-security nexus. The EU, which reiterated the need for a negotiated political solution during the 2002 peace process, as opposed to the U.S./U.K. war paradigm, has embraced the unitary state in its post-war reconstruction aid given to Sri Lanka. After the conclusion of a meeting between Sri Lankan and EU officials regarding human rights, development, and foreign aid in early 2016, the head of the Unit for South and South East Asia from the European Commission Directorate General for International Cooperation and Development stated that said "we hope that the new priorities will assist the government in the implementation of the UNHRC Resolution on Sri Lanka, encompassing the areas of accountability and transitional justice, resettlement and durable solutions, 
governance and reconciliation" (Adaderana 2016). The EU will provide aid worth of 3.8 billion Sri Lankan Rupees for development and mechanisms for accountability recommended by UNHRC resolutions (Sri Lanka Brief 2016). The entire process is termed transitional justice, but in reality it is not only development that has been securitized, but the way in which human rights are framed also has been securitized by aiding the consolidation of the unitary state structure. Human rights have been reduced to criminal justice, abandoning political justice. The latter in the form of a Tamil right to self-determination will problematize the geo-strategic security complex. As mentioned before, delivery of criminal justice has been handed over to the Sri Lankan state. Whilst the EU's promotion of liberal peace in the initial phase of the peace process reflects recognition of political justice, its later position shows the illiberal politics of liberal peace.

\section{Conclusion}

During post-war reconstruction in the North and East of Sri Lanka, the development-security nexus is a development-military nexus. This is to totally dismantle the remaining structural foundations of the collective rights of the Tamils as a distinct nation who claim the territory as their traditional homeland. In the political reconstruction of discourse of transitional justice, the U.S.-led UNHRC resolutions have deleted the word Tamil while recognizing territorial integrity and sovereignty of the Sri Lankan unitary state. Both these approaches serve the geo-strategic complex surrounding the island. Different global actors, mainly China, India, the United States, compete for this strategic asset for different reasons. The best means of keeping the island as a strategic asset is maintaining its unitary state. In fact, dismantling of the 2002 peace process and the subsequent total destruction of the LTTE-led Tamil state in 2009 has to be understood as part the United States' pivot to Asia where it sought to consolidate its sphere of influence in the Indian Ocean Region. In 2003, just before the U.S. invasion of Iraq and during the final peace talks between the Sri Lankan state and the LTTE in Tokyo, the Tamil political leader stated that they intended for the Indian Ocean to be declared a peace zone, which countered the U.S.-led geo-strategic military complex in the region. In analyzing discourses of development, human rights, and human security in post-war contexts, it is important to recognize the geo-strategic complexes across the globe. This is the lens I have used throughout this article in critiquing the political economy of post-war reconstruction in the North and East of Sri Lanka. As Duffield points out, "development has always been linked with what we now understand as counterinsurgency" (Duffield 2007, viii). However, development has been framed as a security measure not only to contain the threat posed by "uninsured lives" to 
the "insured lives" of the West, but also to secure the strategic locations and states across the globe.

The bio-politics of post-war development and democratization which is aimed at controlling the lives of Tamils in Sri Lanka is intrinsically interwoven with geopolitics in the Indian Ocean Region. Without an analysis of the geopolitics of the island's strategic value and its unitary state, an economic critique of biopolitics would not generate formidable resistance to the unitary state and its geo-strategic complex. Civil society groups who engage with victims of war in Sri Lanka need to recognize this aspect. If they do not, their work will be part of an overall hegemonic complex that serves masters whom they do not want to serve. The existing process is aimed at producing subservient subjects who would not question the geo-strategic complex. Both the development-security nexus and reconfiguration of human rights serve this militarized complex. Rather than producing subjects for strategic imperial peace, we need to create space for subjects to produce peace. The Tamils are not helpless victims of war. They have been articulate subjects who exercise political and social agency to the extent of building a state. One Tamil activist stated that "we want to tell our own narrative. We want our version to be there to help create and informed public opinion" (Oakland Institute 2015, 7). It is this agency that has to be recognized as a form of resistance to the dominant geo-strategic complex that combines militarism and neo-liberalism. It is only then that ambiguity of liberal peace can be overcome by transforming it into just peace. In conclusion, the moves towards peacebuilding undertaken by the civil society need to adopt the geo-strategic lens and oppose the development-security nexus of militarization and individualization of human rights. Without such a perspective, the island will continue to plunge deeper into the whirlpool of the geo-strategic military complex, which contributes to further polarization between Tamils and Sinhalese with the reinforcement of Sinhala hegemony over the Tamils.

\section{Notes}

1. There are two interrelated meanings of bio-politics which were developed by Michel Foucault. Firstly, bio-politics means exercising power over bodies and brains through various tools of control such as communication networks, welfare systems, etc. Secondly, this form of power regulates social life "from its interior, following it, interpreting it, absorbing it, and articulating it" (Hardt and Negri 2000, 23-24). In this article, the discourses of democratization and development and the associated ideologies are treated as tools of control that constitute bio-politics. 


\section{References}

A Correspondent. 2012. "Notes on the Military Presence in Sri Lanka’s Northern Province." Economic \& Political Weekly xlviI (28): 34-40.

Adaderana. 2016. "EU to revise development strategy for Sri Lanka." May 31. http://www. adaderana.lk/news.php?nid=35479\&utm_source=twitterfeed\&utm_medium=twitter (accessed January 10, 2017).

Ameen, Azzam. 2016. "Sri Lanka president wants 'internal' war crimes court." $B B C$, January 21. http://www.bbc.com/news/world-asia-35376719 (accessed April 30, 2017).

Agnell, Marisa. 1998. "Understanding the Aryan Theory." In Culture and Politics of Identity in Sri Lanka, eds. Mithran Tiruchelvam and C.S. Dattathreya, 41-71. Colombo: International Centre for Ethnic Studies.

Commission on Human Security. 2003. Human Security Now. New York: Oxford University Press.

DailyFT. 2015. “US praises Sri Lanka's success in rebuilding and reconciliation.” Dec 15. http://www.ft.lk/article/509097/US-praises-Sri-Lanka-s-success-in-rebuilding-andreconciliation (accessed April 30, 2017).

Daily Mirror. 2012. "No more displaced people in SL from today." Sept 25. http://www. dailymirror.lk/news/22156-no-more-displaced-people-in-sl-from-today.html (accessed October 8, 2016).

Duffield, Mark. 2001. Global Governance and the New Wars: The Merging of Development and Security. London: Zed.

Duffield, Mark. 2005. "Human Security: Linking Development and Security in an Age of Terror." Paper presented at the 11th General Conference of the European Association of Development Research and Training Institutes (EADI), Bonn, Germany, September 21-24. http://www.msu.ac.zw/elearning/material/1237745194Mark_Duffield.pdf (accessed April 24, 2017).

Duffield, Mark. 2007. Development, Security and Unending War: Governing the World of Peoples. London: Polity.

Fernando, Jude Lal. 2013. "War by other Means: Expansion of Sinhala Buddhism into the Tamil Region." In "Post-War" İlam' in Buddhism among Tamils in Tamilakam and İlam, Part 3, Extension and Conclusions, ed. Peter Schalk, 175-238. Uppsala: Uppsala Universitet.

Hardt, Michael, and Antonio Negri. 2000. Empire. Cambridge: Harvard University Press.

Höglund, Kristine, and Camilla Orjuela. 2011. "Winning the peace: conflict prevention after a victor's peace in Sri Lanka." Contemporary Social Science 6 (1): 19-37.

IRIN. 2013. "Lack of funding for post-war housing in northern Sri Lanka." July 12. https:// www.irinnews.org/fr/node/253726 (accessed January 5, 2017).

Kerry, John. 2015. "Resolution on Sri Lanka at the 30th Session of the UN Human Rights Council - Press Statement." Mission of the United States, Geneva, Switzerland, September 24. https://geneva.usmission.gov/2015/09/25/resolution-on-sri-lanka-atthe-30th-session-of-the-un-human-rights-council/ (accessed December 23, 2016).

Korean Herald. 2016. “Korea to join Sri Lanka’s \$63b smart city project.” May 24. http:// www.koreaherald.com/view.php?ud=20160524000761 (accessed January 5, 2017). 
Kurukulasuriya, Lasanda. 2017. “Assistance’ or Espionage.” Daily Mirror, January 7. http:// www.dailymirror.lk/article/-Assistance-or-Espionage--121829.html (accessed January 8 , 2017).

Japan Consortium of International Cooperation in Cultural Heritage. 2015. Survey of Protection and Utilization of Cultural Property in Northern and Northeastern Provinces of Sri Lanka. Tokyo: Japan Consortium of International Cooperation in Cultural Heritage.

Jeganathan, Pradeep. 1995. "Authorizing History, Ordering Land: The Conquest of Anuradhapura." In Unmaking the Nation: The Politics of Identity and History in Modern Sri Lanka, eds. Pradeep Jeganathan and Qadri Ismail, 106-136. Colombo: Social Scientists' Association.

Maatram Foundation. 2015. Understanding Post-War Land Issues in Northern Sri Lanka. Vavuniya, Sri Lanka: The Maatram Foundation.

McGinty, Roger, and Andrew Williams. 2009. Conflict and Development. London: Routledge.

Miller, Phil. 2014. Britain's Dirty War against the Tamil People, 1979-2009. Bremen: Internationaler Menschenrechtsverein Bremen.

Moorcroft, Paul. 2013. Total Destruction of the Tamil Tigers: The Rare Victory of Sri Lanka's Long War. Barnsley: Pen and Sword Military.

Oakland Institute. 2015. The Long Shadow of War: The Struggle for Justice in Postwar Sri Lanka. Oakland/California: The Oakland Institute.

Outlook. 2007. "Uncle Sam in Sri Lanka." March 14. http://www.outlookindia.com/ website/story/uncle-sam-in-sri-lanka/234130 (accessed January 10, 2017).

Perera, Sasanka. 1996. Newton Gunasinghe: Selected Essays. Colombo: Social Scientists' Association.

Permanent People's Tribunal. 2010, 2013. People’s Tribunal on Sri Lanka. Rome: Permanent People's Tribunal and Irish Forum For Peace in Sri Lanka.

Ponnambalam, Satchi. 1981. Dependent Capitalism: The Sri Lanka Economy in Crisis, 19481980. London: Zed Press.

Richmond, Oliver P. 2011. A Post-Liberal Peace. New York: Routledge.

Shani, Girogio. 2014. "Human Security at Twenty: A Post-Secular Approach." Journal of Human Security Studies 3 (2): 120-135.

Sirimanna, Bandula. 2010. "Chinese and Indian companies dominate Sri Lanka’s mega project business.” Sunday Times, September 5. http://www.sundaytimes.lk/100905/ BusinessTimes/bt21.html (accessed January 5, 2017).

Sirimanna. Bandula. 2012. "China to Build Military Housing in North East." Sunday Times, August 26. http://www.sundaytimes.lk/120826/news/china-tobuild-military-housingin-north-east-10124.html (accessed January 2, 2017).

Sooka, Yasmin. 2014. An Unfinished War: Torture and Sexual Violence in Sri Lanka, 20092014. London: BAR Human Rights Committee of England.

Subramaniam, Nirupama. 2012. "Sri Lankan Army still has vast presence in North \& East." The Hindu, September 19. http://www.thehindu.com/news/sri-lankan-army-still-hasvast-presence-in-north-east/article3915391.ece (accessed January 12, 2017).

Sri Lanka Brief. 2016. "EU to Provide LKR 38 Billion for Development Cooperation with Sri Lanka.” May 30. http://srilankabrief.org/2016/05/eu-to-provide-lkr-38-billion-fordevelopment-cooperation-with-sri-lanka/ (accessed January 10, 2017). 
Tamilnet. 2016. "Encouraged by US appeasement, SL military strengthens genocidal grip on North." July 15. http://www.tamilnet.com/art.html?catid=13\&artid=38327 (accessed January 10, 2017).

Tamilnet. 2017. "8,500 landowner families remain uprooted due to Sinhala militarisation of Jaffna District.” January 8. http://www.tamilnet.com/art.html? catid=13\&artid=38545 (accessed January 9, 2017).

U.S. Embassy in Sri Lanka. 2016. “U.S. Welcomes Sri Lanka’s Contribution to Security in the Indo-Asia- Pacific Region.” November 29. https://lk.usembassy.gov/u-s-welcomessri-lankas-contribution-security-indo-asia-pacific-region/ (accessed December 30, 2016).

United Nations. 2011. "Report of the Secretary-General's Panel of Experts on Accountability in Sri Lanka." http://www.un.org/News/dh/infocus/Sri_Lanka/POE_Report_Full.pdf (accessed December 23, 2016).

United Nations. 2012. "Report on the Secretary-General's Internal Review Panel on United Nations Actions on Sri Lanka." http://www.un.org/News/dh/infocus/Sri_Lanka/The _ Internal_Review_Panel_report_on_Sri_Lanka.pdf (accessed December 23, 2016).

United Nations General Assembly. 2013. "22/...Promoting reconciliation and accountability in Sri Lanka.” A/HRC/22/L.1/Rev.1, March 19. https://documents-dds-ny.un.org/ doc/RESOLUTION/LTD/G13/122/61/PDF/G1312261.pdf?OpenElement (accessed December 20, 2016).

USAID Sri Lanka. 2016. “About Sri Lanka." https://www.usaid.gov/sri-lanka (accessed January 10, 2017).

Word Bank. 2011. World Development Report: Conflict, Security, and Development. Washington D.C.: World Bank.

Jude Lal Fernando is an Assistant Professor in the Irish School of Ecumenics, Trinity College Dublin, and the Director of the Trinity Centre for Post-Conflict Justice where he teaches in the postgraduate programmes of International Peace Studies, Intercultural Theology, and Interreligious Studies (Dublin), and Conflict Resolution and Reconciliation (Belfast). He has published two books, edited one, and written many articles on issues of human rights, geo-politics, religions, peace and conflict. He has worked as Visiting Professor in Tampere Peace Research Institute in Finland, Uppsala University in Sweden, Ritsumeikan and Sophia Universities in Japan. Email: fernanla@tcd.ie. 